\title{
An Anaerobic Titration Assembly for Spectrophotometric Use ${ }^{1}$
}

\author{
G. P. FOUST, B. D. BURLEIGH, JR., S. G. MAYHEW, \\ C. H. WILLIAMS, JR., AND V. MASSEY \\ Department of Biological Chemistry, The University of Michigan and the \\ Veterans Administration Hospital, Ann Arbor, Michigan 48104
}

Received June 14, 1968

Much useful information of a quantitative nature can be obtained with redox-active proteins by anaerobic titration with reducing substrates or chemical reductants such as sodium dithionite. We have used successfully for many years anaerobic spectrophotometer cells equipped with either two or four side arms from which known amounts of titrant can be added (1). This technique gives only a limited amount of information for a given quantity of enzyme. The need is obvious for a sensitive and versatile apparatus with which a large number of experimental points may be obtained with a single solution of enzyme. Such a titration apparatus is described in this communication.

\section{MATERIALS AND METHODS}

A diagram of the apparatus is shown in Figure 1. The apparatus consists of two units: the titration assembly (composed of the buret A and the spectrophotometer cell B) and the titrant preparation unit C. Sections A, B, and $\mathrm{C}$ can each be manipulated without disturbing anaerobic conditions in any other section. Except for the Teflon needle with a Kel-F hub (which is internal to the system) the entire apparatus is constructed of glass and quartz.

All stopcocks and standard taper joints were obtained from Eck and Krebs Inc. (Long Island City, New York 11101). The microburet is a Kimex $370220.2 \mathrm{ml}$ pipet graduated in $0.001 \mathrm{ml}$ divisions. Corning Glass 3320 was fused between the "hard" pipet glass and the "softer" Pyrex glass forming a strong "gradcd" scal. The luer joint was obtained from Ace Glass Inc. (Vineland, New Jersey 08360) and the Teflon needle with

\footnotetext{
'Supported by a grant from the U. S. Public Health Service (GM 11106), and by a U. S. P. H. S. predoctoral fellowship (1-F1-GM-33,46601) to G. P. Foust.
} 


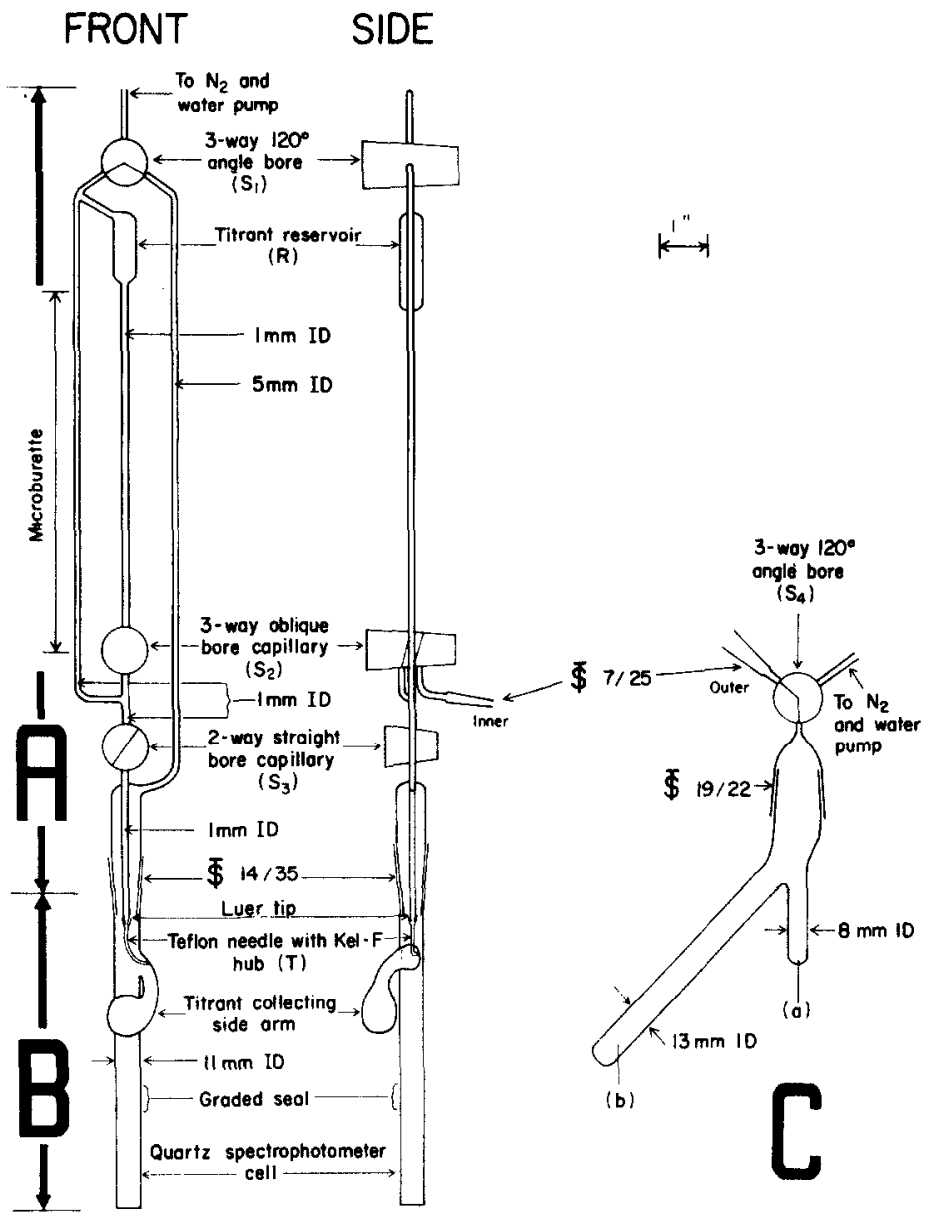

FIg. 1. Titration apparatus. $S_{1}, S_{2}, S_{3}$ and $S_{4}$ are high-vacuum, hollow plug stopcocks. The microburet is a $0.2 \mathrm{ml}$ pipet graduated in $0.001 \mathrm{ml}$ units. For further details see text.

a Kel-F hub was purchased from Hamilton Company. The fused quartz spectrophotometer cell with a quartz to Pyrex graded seal was a product of Precision Cells Inc. (New York, N. Y. 10013).

Although the apparatus appears somewhat fragile and unstable we have found it quite easily manageable. Additions of $5 \mu \mathrm{l}$ can be made easily and reproducibly and with caution $1 \mu \mathrm{l}$ additions are possible. The apparatus has been used in a Cary model 14 spectrophotometer. The spectrophotometer cell of $\mathrm{AB}$ is placed directly into the unmodified sample compartment cell holder and the entire apparatus is stable with no additional support. A black cloth is used to protect the photo- 
multiplier from stray light. Joints and stopcocks are lubricated with high-vacuum stopcock grease (Apiezon $\mathrm{N}$ obtained from Edwards High Vacuum Itd., Manor Royal, Crawley, Sussex, England). A minimum amount of grease is applied to the stoppers and softened over a gas flame immediately before seating them in their sockets. This technique successfully eliminates air lines and avoids trapping excess grease in the stopper bores. Anaerobic conditions are achieved by at least 6 cycles of water pump evacuation $\left(\sim 3\right.$ torr) followed by equilibration with $\mathrm{N}_{2}$ purified with Fieser's solution. All titrations are carried out under 1 atmosphere of $\mathrm{N}_{2}$. The operating procedure for the preparation and standardization of oxygen-sensitive titrants and their subsequent use in titrations will be described.

Solid weighed titrant is transferred via a small funnel into side arm $\mathrm{C}(\mathrm{a})$; solvent is pipetted into the main chamber $\mathrm{C}(\mathrm{b})$ and freed of dissolved $\mathrm{O}_{2}$ (as described above) via $\mathrm{S}_{4}$. The solution is prepared by tipping and mixing. A suitable standard oxidant solution is pipetted into the spectrophotometer cell $\mathrm{B}$ and $\mathrm{AB}$ is assembled as shown. The entire titration assembly is made anaerobic via $S_{1}$ and left under a slight negative pressure. Unit $\mathrm{C}$ is attached to the titration assembly via the $7 / 25$ joint and the remaining dead spaces are filled with $\mathrm{N}_{2}$. After rotating $\mathrm{C}$ by $180^{\circ}$ from the position shown in Figure 1 , the titrant reservoir, $R$, is filled via $S_{2}$ and $S_{4}$. (The flow of solution into the reservoir is more easily controlled when the pressure differential is small.) $\mathrm{C}$ is disconnected from $\mathrm{AB}$ and the excess titrant is stored for later use. By manipulating the stopcocks $S_{2}$ and $S_{3}$, the buret and all capillary dead spaces are filled with titrant, and a small amount is allowed to flow into the titrant collecting side arm. (The Teflon tip $\mathrm{T}$ is bent so that it delivers titrant either into the side arm or, by rotation of either unit A or B, into the main part of the cell. In both positions $\mathrm{T}$ must touch the wall of $\mathrm{B}$. This is essential to ensurc quantitative transfer of titrant.) $\mathrm{A}$ is rotated $180^{\circ}$ about $\mathrm{B}$ and the titration is begun. Aliquots of titrant are added to the wall of $B$ by operating $S_{3}$. After each addition, the device is repeatedly tippcd so that solution flows over the Teflon tip, washing titrant into the main chamber. This ensures quantitative transfer and thorough mixing. Following the standardizacion titration, stopcocks $\mathbf{S}_{1}$ and $\mathbf{S}_{3}$ are closed so that anaerobic conditions in the buret and reservoir are maintained, and $\mathrm{A}$ and $\mathrm{B}$ are disconnected. A $2.5 \mathrm{ml}$ volume of the solution to be titrated is introduced into $\mathrm{B}, \mathrm{A}$ and $\mathrm{B}$ are reassembled, and the system is made anaerobic via $\mathbf{S}_{1}$. The $\mathrm{O}_{2}$-contaminated titrant in the Teflon tip is discharged into the side arm by flushing with fresh titrant, and subsequent operations are carried out as described for the standardization titration. 


\section{RESULTS AND DISCUSSION}

The performance of the apparatus is illustrated by an experiment in which a solution of dithionite was standardized by titration into lumiflavin-3-acetic acid, a two reducing equivalent acceptor. An experimentally determined extinction coefficient of $1.08 \times 10^{4} M^{-1} \mathrm{~cm}$ for oxidized minus reduced flavin at $445 \mathrm{~nm}$ was used. Figure 2 shows the spectra of the oxidized material and those obtained after each addition

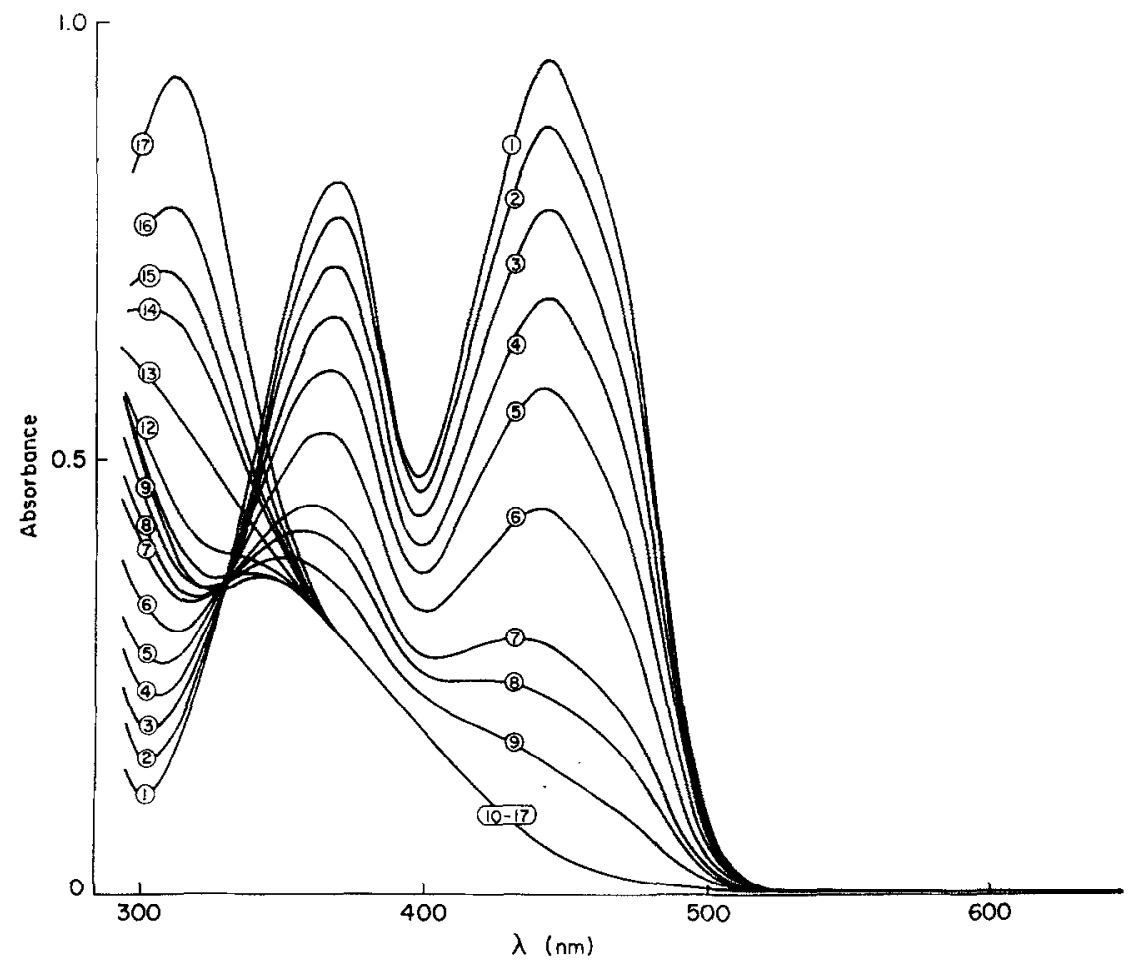

Fic. 2. Anaerobic titration of lumiflavin-3-acetic acid with dithionate $(0.04 \mathrm{M}$ byrophosphate buffer, pH 8.3) at $20^{\circ} \mathrm{C}$. Volume after anaerobosis (detcrmined spectrophotometrically) $2.41 \mathrm{ml}$. Spectra are not corrected for dilution.

$\begin{array}{cccc}\text { Spectrum } & \mu l \mathrm{~S}_{2} \mathrm{O}_{4}-\text { added } & \text { Spectrum } & \mu l \mathrm{~s}_{2} \mathrm{O}_{4}-\text { added } \\ 1 & 0 & 9 & 119 \\ 2 & 24 & 10 & 133 \\ 3 & 36 & 11 & 137 \\ 4 & 50 & 12 & 146 \\ 5 & 63 & 13 & 169 \\ 6 & 80 & 14 & 193 \\ 7 & 100 & 15 & 206 \\ 8 & 109 & 16 & 224 \\ & & 17 & 259\end{array}$




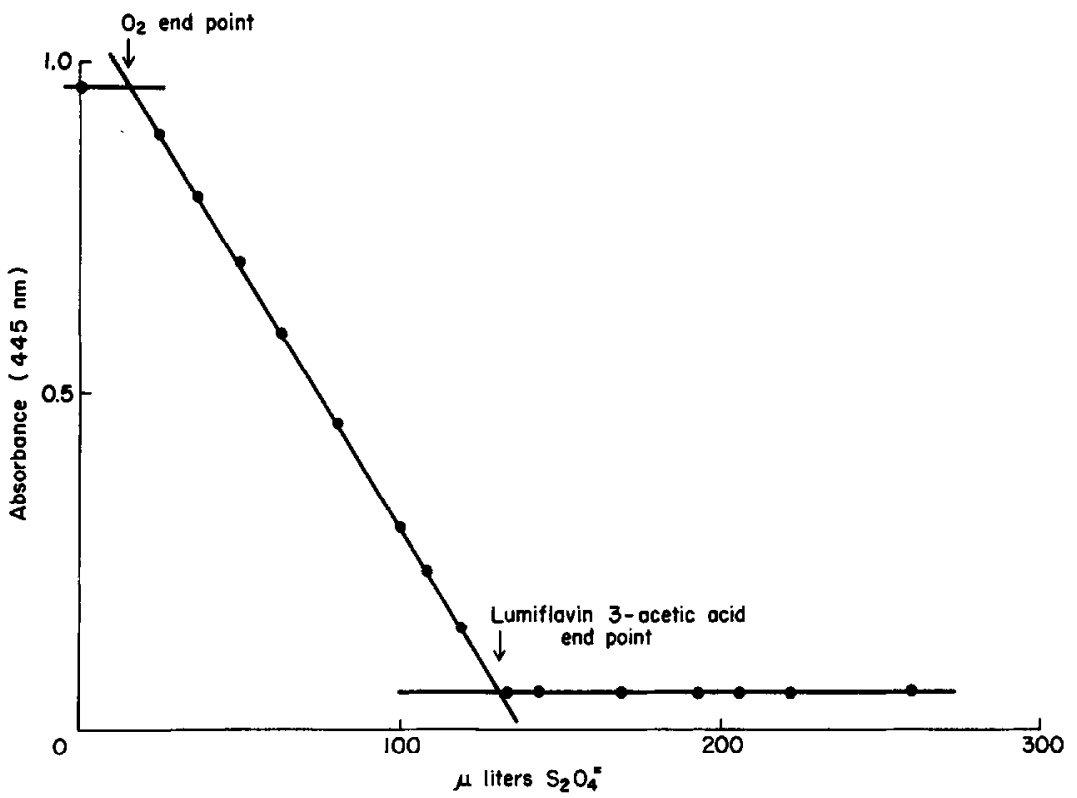

Fig. 3. Titration of lumiflavin-3-acetic acid with dithionite: plot of data of Figure 2. All points corrected for dilution.

of dithionite. Figure 3 is a plot of the absorbance at $445 \mathrm{~nm}$ vs. microliters dithionite added. Figures 2 and 3 indicate reduction of fully oxidized to fully reduced flavin with very little production of semiquinone ${ }^{2}$ (additions 1-10). Additions 11-17 show the accumulation of dithionite $\left(\lambda_{\max }=315 \mathrm{~nm}\right)$. The first end point in Figure 3 is due to residual $\mathrm{O}_{2}$ contamination of the $\mathrm{N}_{2} . \mathrm{O}_{2}$ contamination from experiment to experiment varied over the range from 7 to $30 \mathrm{~m} \mu$ moles and all calculations

TABLE 1

Titrations of Lumiflavin 3-Acetic Acid with Dithionite

\begin{tabular}{ccc}
\hline Day & Operation & $\begin{array}{c}\mathrm{S}_{2} \mathrm{O}_{4}-\text { concentration, } \\
\mathrm{m} M\end{array}$ \\
\hline 1 & Dithionite solution prepared & 1.74 \\
2 & A refilled from C & 1.82 \\
4 & None-solution stored in A & 1.76 \\
& from Day 2 & 1.78 \\
6 & A refilled from C & \\
\hline
\end{tabular}

${ }^{2}$ Maximal semiquinone obtainable under these conditions as determined by EPR is approximately $1 \%$ of the total flavin (2). 
were corrected for the observed contamination. Use of the gas train described in the accompanying paper (3) reduced $\mathrm{O}_{2}$ contamination below levels here detectable. Numerous enzyme samples were titrated with the dithionite solution described and standardizations were performed periodically to check for $\mathrm{O}_{2}$ contamination: results of the standardizations are given in Table 1 .

The apparatus has been employed successfully in anaerobic redox titrations of enzyme solutions and in studying the thermodynamics and kinetics of protein reactions in $\mathrm{O}_{2}$-sensitive redox states.

\section{SUMMARY}

An anaerobic titration apparatus capable of titrations of $2.5 \mathrm{ml}$ of solution with microliter quantities of titrant is described. Numerous samples can be titrated with the same stock solution and back titrations with different titrants are possible. No detectable $\mathrm{O}_{2}$ leaks $(5 \mathrm{~m} \mu$ moles of $\mathrm{O}_{2}$ or greater) were observed over a 6 day period. Biochemical applications of the apparatus are discussed.

\section{ACKNOWLEDGMENT}

We are indebted to Dr. P. Nemmerich for a generous gift of lumiflavin-3acetic acid.

\section{REFERENCES}

1. Massey, V., Gibson, Q. H., and Veeger, C., Biochem. J. 77, 341 (1960).

2. Ehrenberg, A.. Muller, F., and Hemmerich, P., European J. Biochem. 2, 286 (1967).

3. Burleigh, B. D., Jr., Foust, G. P., and Williams, C. H., Jr., Anal. Biochem.. this issue. 